\title{
JOB SATISFACTION OF POLYTECHNIC COLLEGE LECTURER IN VIRUDHUNAGAR DISTRICT
}

\author{
Dr. J. Kamatchi Eswaran, \\ Assistant Professor of Commerce, \\ V.H.N. Senthi Kumara Nadar College (Autonomous), Virudhunagar. \\ A.Venkatesh Boopathy, \\ Lecturer in Modern Office Practice, \\ V.S.V.N.Polytechnic College (Autonomous), Virudhunagar
}

\begin{abstract}
Job satisfaction is of vital importance for the growth of any field. In every field, everyone gets job satisfaction because that is correlated with life satisfaction. Hence Job satisfaction is essential for any institution which improves the growth of any educational institution.

Job satisfaction refers to a person's feelings of satisfaction on the job, which acts as a motivation to work. Here, it is not merely satisfaction, happiness or self-contentment, but is always in relation to the job. If a human being likes the job intensively, he/she will experience high job satisfaction. If he/she dislikes the job intensively, he/she will experience high job dissatisfaction. It is essentially related to human needs and their fulfillment through work. Job satisfaction is generated by an individual's perception of how well his/her job on the whole satisfies his/her various needs. Hence, an in-depth investigation on job satisfaction of polytechnic college lecturers with particular reference to selffinance polytechnic college lecturers in Virudhunagar district is carried out in this study.
\end{abstract}

Key words: Job satisfaction - Educational institution - Self concept - learning, motivation

\section{INTRODUCTION}

Job satisfaction is a motivation factor as well as an integration factor. High job satisfaction contributes to organizational commitment, job involvement, better physical and mental health and quality life to the employees. On the other hand, job dissatisfaction leads to negative institutional climate. If a lecturer likes his/her job more, he/she is likely to live longer. The logic behind the statement is if he/she gets job satisfaction, he/she will be eager to work more through which his/her income level my increase, he/she may get promotion and his/her status may become improved in the society. On the other hand, if he/she dislikes his work, always he/she will spoil the work. It creates tension, mental torture and physical problems. Hence there may be positive or negative consequences regarding job satisfaction. When the lecturers are depressed in their work, they feel stress which is considered as a slow poison.

Many psychologists conducted approach regarding job satisfaction and from the approaches, job satisfaction theories have been developed. From the approaches, it is understood that job satisfaction is a global term, which includes not only the adjustment made by the employee in his job environment only but also the adjustment of the individual in several other cases. There are many factors, which influence the job satisfaction of employees but personal factors, pay and reward and work environment and characteristic of job factors are the most important one, which determine the job satisfaction. If a person is satisfied in his/her work, he/she will be interested to continue the job and a person is dissatisfied in his/her work, he/she will leave. Job satisfaction has positive effect regarding productivity, performance and goodwill of the institution

Educational institution is a service institution which has direct touch with the public by rendering eminent services. The role of educational institutions cannot be measurable because they engaged in meeting the aspirations of our pupils. They may also offer valuable services to the society. It is a duty of the management to take steps to increase satisfaction level of the employees. This will bring the institution into a mountainous height. 


\section{STATEMENT OF THE PROBLEM}

Lecturers in Polytechnic colleges undergo stressful situation due to personality, attitude, perception, level of learning, motivation, Interpersonal relations, physical work environment, pay structure, distance from residence and work schedule. It expresses the amount of agreement between one's expectations of the job and the rewards that the job provides. Since a job is an important part of life, job satisfaction influences one's general life satisfaction.

Unless the job satisfaction among the faculties is increased, it would affect the outcome of quality students and also the establishment of academic excellence. Hence, an in-depth investigation on job satisfaction of polytechnic college lecturers with particular reference to selffinance polytechnic college lecturers in Virudhunagar district is carried out in this study.

\section{SCOPE OF THE STUDY}

The scope of my study is, limited to assessing the level of job satisfaction of self-finance polytechnic college lecturers only among 16 polytechnic colleges in virudhunagar district. Aided polytechnic college lecturers are excluded from the study. The study is applicable only to the job satisfaction of self-finance polytechnic college lecturers not other lecturers in the professionals and art colleges.

\section{OBJECTIVES OF THE STUDY}

The confined objectives of the present study are:

- To present the role of Technical education in India.

- To examine the profile of the polytechnic college lecturers in Virudhunagar District.

- To measure the factors influencing the level of job satisfaction among the polytechnic college lecturers in Virudhunagar District.

- To assess the stress perception factors of selffinance polytechnic college lecturers in Virudhunagar District.

- To offer suggestions for improving the satisfaction level of polytechnic college lecturers in Virudhunagar District based upon my study.

\section{HYPOTHESES}

Based on the objectives of the study, there are seven hypotheses have been framed by using appropriate statistical tools.

\section{RESEARCH DESIGN AND METHODOLOGY}

Data is mainly based on primary and secondary sources where primary data have been collected from the polytechnic college lecturers in Virudhunagar district by way of a s structured questionnaire prepared for the purpose in order to obtain the detailed facts relating to the objectives of the study. Secondary data have been collected from advanced books, specified journals, magazines, newspapers, research proceedings and various websites.

\section{PRE-TEST}

A pilot study was conducted among 25 polytechnic college lecturer in Virudhunagar District. Based on the feedback from the pretest, certain modifications, additions, deletions and simplifications were carried out. The draft of the questionnaire was prepared to collect the data from polytechnic college lecturers in Virudhunagar District.

\section{SAMPLING DESIGN}

I applied Convenience Random Sampling technique consisting of 560 polytechnic college lecturers in Virudhunagar district. For that Universe is collected from Directorate of Technical Education, Chennaias on 05-05-2014. There are 16 polytechnic colleges which includes 4 Aided polytechnic colleges and remaining 12 are self-finance polytechnic colleges in Virudhunagar District. Among which totally 1680 Self-finance polytechnic college lecturersare employed. The sample respondents were distributed on the basis of strength of teaching staff of self-finance polytechnic one-third of the population was considered feasible for this present study. Thus a sample of 560 lecturers was decided to apply Proportionate Method on total of 1680 polytechnic college lecturers.

STUDY AREA :

My study areas are :

Amathur

Rajapalayam

Venganallur

Alangulam

\author{
Virudhunagar \\ Sattur \\ Sivakasi \\ Aruppukottai
}


International Journal of Engineering Applied Sciences and Technology, 2020

Vol. 5, Issue 3, ISSN No. 2455-2143, Pages 320-326

Published Online July 2020 in IJEAST (http://www.ijeast.com)

Chinnakamanpatti

DISTRIBUTION OF SAMPLE RESPONDENTS

\begin{tabular}{|c|c|c|c|}
\hline S.No. & Name of the Polytechnics & $\begin{array}{c}\text { Total No.of } \\
\text { Lecturers }\end{array}$ & $\begin{array}{c}\text { No. of } \\
\text { Sample } \\
\text { Lecturers }\end{array}$ \\
\hline 1. & Ammaiappar Polytechnic College,Puthur & 82 & 27 \\
\hline 2. & Angel polytechnic College,South Venganallur & 63 & 21 \\
\hline 3. & ArasanGanesan Polytechnic College,Amathur & 110 & 37 \\
\hline 4. & ArulmiguKalasalingam Polytechnic college,Nathampati & 65 & 22 \\
\hline 5. & AyyaNadarJanakiammal Polytechnic College, Chinnakkamanpatti & 59 & 20 \\
\hline 6. & N.A.Manjammal Polytechnic College,Rajapalayam & 82 & 27 \\
\hline 7. & P.A.C.Ramasamy Raja Polytechnic College, Venganallur & 146 & 49 \\
\hline 8. & P.S.R.PolytechnicCollege,Appayanayakenpatti & 188 & 63 \\
\hline 9. & Ramu-Seetha Polytechnic College,Kambikudi & 102 & 34 \\
\hline 10. & S.M.S. Polytechnic College,Alangulam & 64 & 21 \\
\hline 11. & Sivakasi Institute of Printing Technology,AMeenakshipuram & 105 & 35 \\
\hline 12. & Sri Boghar Polytechnic College,Panthanenthal & 92 & 31 \\
\hline 13. & Sri S.Ramasamy Naidu Memorial Polytechnic College, & 102 & 34 \\
\hline 14. & Muthulingapuram & 178 & 59 \\
\hline 15. & Sri Sowdambika Polytechnic College, Aruppukottai & 84 & 28 \\
\hline 16. & Sri Vatsa Polytechnic College, Sattur & 158 & 52 \\
\hline & TirudhunagarS.VellaichamyNadar Polytechnic College, Rosalpatti & $\mathbf{1 6 8 0}$ & $\mathbf{5 6 0}$ \\
\hline
\end{tabular}

\section{PERIOD OF STUDY}

The primary data were collected during the period from June 2017 to May 2018. The survey covered a period of one year.

\section{DATA PROCESSING}

After completing the data collection, data has been processed for coding the data in a computer. Then, the cross tables has been prepared by using SPSS package. Detailed analysis has been done and appropriate tools have been framed to get good results.

\section{FRAME WORK OF ANALYSIS AND STATISTICAL TOOL EMPLOYED}

The analysis of data in a research plays a pivotal role in the sense that it interprets, justifies and proves the hypothesis and the proposals. The judicious blend of analytical tools used has its own impact on the findings of the research, thereby making it highly objective and scientific. In this study, the tools for analysis have been rightly chosen i.e.
1. Percentage Analysis
2. Mean and Standard deviation
3. t-Test
4. F-test

5. One-way Analysis of Variance (ANOVA)

6. Chi Square Test

7. Correlation Coefficient

8. Garrett Ranking

9. Factor Analysis

10. Simple Ranking Technique

11. Likert's Five Point Scaling Technique

\section{CHAPTER CLASSIFICATION}

My study has been segmented into seven chapters.

The first chapter captioned "Introduction and Design of the Study" deals with introduction of the study, statement of the problem, scope of the study, objectives of the study, hypotheses of the study, profile of the study area, research design and methodology, sources of data, sampling design, field work, data processing, research design and methodology of the study, framework of analysis and statistical tools employed, limitations of the study and chapter scheme.

The second chapter listed "Review of Literature" explains the review of previous studies about the job satisfaction and presented in a chronological sequence.

The third chapter deals with "Technical Education - An Overview" which exhibits the historical background of the technical education, powers and duties of staff, government order relating to appointment, promotion and remuneration, workload of self-finance polytechnic college 
lecturers, technical institutions E-Governance portal for Directorate of Technical Education, Government of Tamil nadu and Technical Education quality improvement programme.

The fourth chaptercaptioned the "Sample Polytechnic College Lecturer - A General Appraisal". This chapter explains the profile related to demographic variables, socio-economic variables and geographical variables of the sample respondents have been covered.

The fifth chapter entitled "Determinants of Job Satisfaction" measures the job satisfaction of polytechnic college lecturers, measures the opinions of the respondents towards characteristic of job, inter-personal relations, pay \& reward and work environment and finding the differences between demographic profile and various aspects of characteristic of job, inter-personal relations, pay \& reward and work environment and overall satisfaction. The relationships among characteristic of job, inter-personal relation, pay \& reward and work environment are assessed.

The sixth chapter titled "Stress among Polytechnic College Lecturer" is about the stress which influence the job satisfaction of polytechnic college lecturer.

The last chapter titled "Summary of Findings, Suggestions and Conclusion" brings out the research report to a logical conclusion by highlighting the summary of the survey findings and by providing valuable suggestions to the polytechnic college lecturers in Virudhunagar District.

\section{MAJOR FINDINGS OF THE STUDY}

From the analysis of the job satisfaction of Polytechnic College Lecturer in Virudhunagar District, the major findings are

Percentage analysis is used for assessing the demographic profile, socio-economic variables and geographic variables of the polytechnic college lecturer.

\section{DEMOGRAPHIC PROFILE OF THE RESPONDENTS}

Demographic variables include age, sex, marital status, family size, number of dependents, type of family, education, number of earning members, monthly salary, accommodation, location of native place, distance between residence and work spot, mode of conveyance, teaching experience and employment status.

college lecturers,

Out of 560 sample polytechnic

- $282(50.4 \%)$ respondents belong to the age group of below 30 .

- 408 (72.9\%) polytechnic college lecturers are male.

- $366(65.4 \%)$ are married respondents.

- 416 (74.3\%) respondents have 3 to 6 dependents in their family.

- 383 (68.4\%)respondents belong to nuclear family system.

\section{SOCIO-ECONOMIC VARIABLES}

- $329(58.8 \%)$ are graduate in Engineering education in polytechnic colleges.

- 378 (67.5\%) respondents have two earning members in their family.

- $223(39.8 \%)$ belong to the income group of Rs. 10,000 to Rs. 15,000 .

- $458(81.8 \%)$ polytechnic college lecturers live in their own house.

- $169(30.2 \%)$ of the respondents have 3-5 years of experience.

- $482(86.1 \%)$ are designated as lecturers in their polytechnic colleges.

- 394 (70.4\%) respondents are full-time lecturers.

\section{GEOGRAPHIC VARIABLES}

- $439(78.4 \%)$ lecturers happen to working in local region.

- $413(73.8 \%)$ lecturers have distance between the residence and work spot below 15 $\mathrm{kms}$ from the polytechnic college.

- 205 (36.6\%) sample polytechnic college lecturers travel by bus to reach the college.

- 303 (54.1\%) lecturers use LCD-Power point for teaching and all are using blackboard as teaching aid.

\section{PERCEPTION OF JOB}

\begin{tabular}{|l|c|c|}
\hline \multicolumn{1}{|c|}{ Characteristics } & Number of Lecturers & Percentage \\
\hline Recruitment & 34 & 6.1 \\
\hline Job security & 28 & 5.0 \\
\hline Training & 20 & 3.6 \\
\hline Pay \& reward & 251 & 44.8 \\
\hline Workload & 66 & 11.8 \\
\hline Inter-personal relationship & 94 & 16.8 \\
\hline
\end{tabular}


International Journal of Engineering Applied Sciences and Technology, 2020

Vol. 5, Issue 3, ISSN No. 2455-2143, Pages 320-326

Published Online July 2020 in IJEAST (http://www.ijeast.com)

\begin{tabular}{|c|c|c|}
\hline Work environment & 67 & 11.9 \\
\hline Total & 560 & 100 \\
\hline
\end{tabular}

- In that table out of 560 polytechnic college lecturers, $251(44.8 \%)$ pay and reward is the dominant perception about the job and followed by inter-personal relationship and the least score goes to training and followed by job security by polytechnic college lecturers

\section{SUGGESTIONS}

On the basis of the findings of the present study, the following suggestions has been made to improve the job satisfaction of self-finance polytechnic college lecturers:

\section{SUGGESTIONS FOR MANAGEMENT}

- The management should recognize the academic excellence of lecturers and award promotions.

- The college management should offer freedom to the lecturers in expressing their opinions related to matters of their interest.

- The polytechnic college management should motivate the lectures to take part in seminars and conferences for enhancing the knowledge.

- The management team should take efforts to improve work environment.

- The college management team should provide annual increments to all the lecturers and incentives to those who have produced good results.

- The polytechnic college management should provide freedom to the lecturers in maintaining discipline in classrooms.

- The management should arrange staff meetings at periodical intervals for the staff to raise their grievances only to get them redressed.

- The management should recruit new hands to prevent existing staff from being overloaded.

- The management team and senior academic staff may form quality circles in the institution as a means to achieve staff empowerment and the growth of the organization.

- The college management is advised to conduct many counseling programmes, workshops and awareness programmes on the research for their faculties. The management may create an opportunity to motivate and develop faculty development programme.

- The management can arrange smart class room facilities for each department and create infrastructural facilities to motivate the polytechnic college lecturers.

\section{SUGGESTIONS FOR LECTURERS}

- It is observed that, the lecturers should constantly update their knowledge in their respective fields.

- It is noted that the lecturers should make themselves not being disturbed by family problems while taking classes.

- The study provides that the polytechnic college lecturers should improve emotional intelligence while dealing with students, peers and superiors to avoid inter-personal conflicts.

- The lecturers should develop effective use on planning to prevent unnecessary anxiety to cover the syllabus towards the end of the semester.

- The lecturers should get adequate feedback at regular intervals to ensure that the teaching has benefited the students.

- It is advisable to the polytechnic college lecturers should offer counseling to the needy students at the staff rooms to make the classroom atmosphere a pleasant one.

- The lecturers should schedule the activities of maintenance of records and registers in such a way that it does not affect regular work schedule.

- It is observed that, the lecturer needs to take care of her health as only gale and healthy 
individuals can deliver the much needed service to the students.

- Polytechnic College Lecturer has to plan the classes in such a way that the students understand the subject effectively by getting feedback from the latter at periodic intervals.

- The academic performance of the students is a cause for worry for a lecturer, as she/he has to analyse the causes for poor performance and determine remedies to rectify the situation, rather than experiencing a spell of stress

- Maintaining quality of work life is very much in the hands of lecturers, they can enhance it by just concentrating on their skills in teaching and updating their knowledge.

- Using modern teaching methods may kindle the interest of the students in learning. Making innovation in teaching methodology may lead to creation of positive attitude towards the lecturer in the minds of students.

- The lecturers must encourage the students to take part in inter-collegiate competitions to promote their communications and leadership skills.

- The lecturers may provide vocational guidance to the students by collecting information from various sources and providing it for the well-being of the students.

- The lecturers of polytechnic colleges may plan their career advancement and take efforts to complete doctorate degree in their respective disciplines. They may also take upon post-doctoral research.

- Probably the most important point to bear in mind when considering the polytechnic college lecturers should make use of library, smart class room facilities to the maximum advantage.

\section{CONCLUSION}

From the present study, I concluded that, the job satisfaction among the polytechnic college lecturers in virudhunagar district are found and the important job satisfaction factors among the faculties are characteristic of job and inter-personal relation. The present study concludes that job satisfaction is eventually seen among the faculties except pay and reward and work environment. The management should take the steps to increase pay, implement reward and provide better work environment which lead the level of job satisfaction of polytechnic college lecturers can also be improved.

\section{REFERENCES}

1. Abouserie, R. 1996. Stress, Coping Strategies and Job Satisfaction in University Academic Staff. Educational Psychology: An International Journal of Experimental Educational Psychology, vol.16, no.1, pp.4956.

2. Abu Saad, I., \& Isralowitz, E. R. 2001. Teachers' Job Satisfaction in Transitional Society within the Bedouin Arab Schools of the Negev. The Journal of Social Psychology, 132(6): 771-781.

3. Adelina Broadbridge, Vivien Swanson and Christine Taylor (2003), "Changes in Retailing, Impact on Job Demands, Satisfactions and the work/home interface", The ICFAI Journal of OrganisationalBehaviour, 2 (1), February, pp.21-32.

4. Asha Balagangadharan and A. Afneeda, (2004), "A comparative study of the personality and stress tolerance level of rheumatoid arthriticand osteoarthristic patients with that of normal", Journal of Psychological Researchers, 48 (2), pp.71-76.

5. Astrauskaite, M., Vaitkevicius, R., Perminas, A. 2011. Job Satisfaction Survey: A Confirmatory Factor analysis based on Secondary School Teachers' sample. International Journal of Business and Management, Vol. 6, No. 5, pp.: 41-50.

6. Bhagat, R. S. 1982. Conditions under Which Stronger Job Performance-Job Satisfaction Relationships May Be Observed: A Closer Look at Two Situational Contingencies. The Academy of Management Journal, Vol. 25, No. 4, pp. 772-789.

7. Castilo, J., X., \& Cano, J. Factors Explaining Job Satisfaction Among Faculty. Journal of Agricultural Education, Vol. 45, No. 3, pp. 65-74.

8. Celia, B., R. Impact of Work Related Demographic Factors on Job Satisfaction of Teaching Staff in Self Financing Engineering 
Colleges. International Journal of Exclusive Management Research, Vol.2, No.3.

9. Cheng, W., Ellsworth, R., \& Hawley, D. 2008. Job satisfaction and career persistence of beginning teachers. International Journal of Educational Management, Vol. 22, No. 1, pp.: 48-61.

10. Dr.S.N.Bandopadhyay, "Job satisfaction with Jobs Anxiety and Personality Variables",

International Journal of Training and Development, Journal 32 (3) July September 2002.

11. Eyupoglu, S. Z., \& Sanar, T. 2016. Job satisfaction: Does rank make a difference? African Journal of Business Management, Vol.3 (10), pp. 609-615.

12. Fatima, K. (2017). Employee satisfaction in higher education: the case of academic and administrative staff in Turkey. Career Development International, Vol.8, No.7.

13. Feather, N., T., \& Rauter, K., A. 2018. Organisational Citizenship Behaviors in Relation to Job Status, Job Insecurity, Organizational Commitment and Identification, Job Satisfaction and work values. Journal of Occupational and Organizational Psychology, 77, 81-94.

14. Felps, W., Mitchell, T. R., Hekman, D. R., Lee, T. W., Holtom, B. C., \& Hamen, W. S. 2019. Turnover Contagion: How co-workers' job embeddedness and job search behaviors influence quitting. Academy of Management Journal, Vol.52, No.3, pp.: 545-561. 